\title{
A simple HPLC method for the determination of halcinonide in lipid nanoparticles: development, validation, encapsulation efficiency, and in vitro drug permeation
}

\author{
Clarissa Elize Lopes, Gisele Langoski, Traudi Klein, Priscileila Colerato Ferrari*, \\ Paulo Vitor Farago
}

Department of Pharmaceutical Sciences, State University of Ponta Grossa, Ponta Grossa, Paraná, Brazil

\begin{abstract}
Halcinonide is a high-potency topical glucocorticoid used for skin inflammation treatments that presents toxic systemic effects. A simple and quick analytical method to quantify the amount of halcinonide encapsulated into lipid nanoparticles, such as polymeric lipid-core nanoparticles and solid lipid nanoparticles, was developed and validated regarding the drug's encapsulation efficiency and in vitro permeation. The development and validation of the analytical method were carried out using the high performance liquid chromatography with the UV detection at $239 \mathrm{~nm}$. The validation parameters were specificity, linearity, precision and accuracy, limits of detection and quantitation, and robustness. The method presented an isocratic flow rate of $1.0 \mathrm{~mL} \cdot \mathrm{min}^{-1}$, a mobile phase methanol:water $(85: 15 \mathrm{v} / \mathrm{v})$, and a retention time of $4.21 \mathrm{~min}$. The method was validated according to international and national regulations. The halcinonide encapsulation efficiency in nanoparticles was greater than $99 \%$ and the in vitro drug permeation study showed that less than $9 \%$ of the drug permeated through the membrane, indicating a nanoparticle reservoir effect, which can reduce the halcinonide's toxic systemic effects. These studies demonstrated the applicability of the developed and validated analytical method to quantify halcinonide in lipid nanoparticles.
\end{abstract}

Uniterms: Halcinonide/encapsulation efficiency. Halcinonide/quantification. Polymeric lipid-core nanoparticles. Solid lipid nanoparticles. Topical administration. Toxicity. High performance liquid chromatography/method validation.

\section{INTRODUCTION}

Topical corticosteroids or glucocorticoids are widely employed in dermatosis treatments due to their potent anti-inflammatory and anti-proliferative effects (Hengee et al., 2006; Guichard et al., 2015). However, the use of topical glucocorticoids can result in several local and adverse systemic effects, such as epidermis, dermis, or even subcutaneous tissue atrophy, resulting in irreversible stretch marks and in disorder of the wound-healing processes. Adverse systemic effects include body weight increase, Cushing's syndrome, hypertension, diabetes mellitus, growth retardation, osteoporosis, peptic ulcer, and gastritis (Schacke, Docke, Asadullah, 2002; Senyigit, Ozer, 2012).

\footnotetext{
*Correspondence: P. C. Ferrari. Departamento de Ciências Farmacêuticas. Universidade Estadual de Ponta Grossa. Av. General Carlos Cavalcanti, 4748 - Uvaranas - 84030-900 - Ponta Grossa, PR, Brazil. Phone: 55-42-3220 3122. E-mail: priscileila@hotmail.com / pcferrari@uepg.br
}

Halcinonide $\left(\mathrm{C}_{24} \mathrm{H}_{32} \mathrm{ClFO}_{5}\right.$; $\left.\mathrm{MW}: 454.96 \mathrm{Da}\right)$ or (11 $\beta, 16 \alpha)$-21-chloro-9-fluoro-11-hydroxy-16, 17-[(1-methylethylidene)bis (oxy)]pregn-4-ene-3, 20 -dione (Figure 1) is a high-potency topical corticosteroid, which is a hydrocortisone derivative and whose modifications alter its absorption, potency, and adverse effects. Halcinonide is classified as a Class II potency corticosteroid (Taheri, Feldman, 2012), whose characteristics include being a white crystalline powder, soluble in acetone and in chloroform, slightly soluble<smiles></smiles>

FIGURE 1 - Chemical structure of halcinonide. 
in alcohol and in ethyl ether, insoluble in water and in hexanes.

Halcinonide is administered by topical via. However, due to its high potency, it displays dose-dependent toxicity and local and systemic adverse effects. In order to reduce the drug toxicity and to improve its action, halcinonide can be encapsulated into nanostructured systems, such as nanoparticles, which promote a controlled release of the drug in specific sites (Schaffazick, Guterres, 2003; Senyigit, Ozer, 2012). Nanostructured systems, such as nanoparticles, are submicron size ranged-usually spherical-drug carriers. Lipid nanoparticles are widely used to carry lipophilic drugs and they are constituted by biocompatible and non-toxic lipids and may to be associated with polymers (Kelidari et al., 2015). They present advantages in the drug delivery control, such as good local tolerability, high encapsulation rate for lipophilic substances, and small particle size, which provide close contact with the stratum corneum. Moreover, they can create a film on the skin surface (Maia et al., 2000)

In order to reduce the halcinonide toxicity in topical use, lipid nanoparticles, such as solid lipid nanoparticles (SLN) and polymeric lipid-core nanoparticles (LCN), were developed. SLNs are a colloidal carrier system for targeting drugs and are appropriate for use in cases of inflamed and damaged skin. They can favor drug penetration in the skin, maintaining a sustained release to avoid systemic absorption. They also reduce skin irritation due to their skin-targeting effect (Chen et al., 2006; Madan et al., 2014; Shah et al., 2015). LCNs are nanostructured devices in which a polymer wall surrounds the lipid core. They can stabilize the encapsulated substances and control the release of the drug to improve its effectiveness, acting as reservoir systems at the epidermis, and retaining themselves at the outermost layers of the skin (Jäger et al., 2007; Venturini et al., 2011; Coradini et al., 2014; Fiel et al., 2014; Brum et al., 2015).

The literature reports just one high performance liquid chromatography (HPLC) method that determines halcinonide from different sample types (Kirschbaum et al., 1980). However, no study involving the quantification of halcinonide entrapped in lipid nanoparticles was submitted for the mandatory validation process. We developed and validated a simple, sensitive, and specific HPLC-UV method to determine the presence of halcinonide in lipid nanoparticles. Subsequently, this validated method was successfully used to quantify the amount of halcinonide encapsulated in these lipid nanostructured systems and to evaluate the in vitro drug permeation.

\section{MATERIAL AND METHODS}

\section{Chemicals and reagents}

Halcinonide 99,2\% (Fagron, Anápolis, GO, Brazil), poly ( $\varepsilon$-caprolactone) $(M w=10000-14000 \mathrm{~g} / \mathrm{mol}$, SigmaAldrich, St. Louis, MO, USA), Span $60^{\circledR}$ (sorbitan stearate; Sigma Aldrich,St. Louis, MO, USA), Tween $80^{\circledR}$ (polysorbate 80 ; Deleware, Porto Alegre, Brazil), capric/caprylic acid triglycerides (Focus Química, São Paulo, Brazil), stearic acid (Fagron, Anápolis, GO, Brazil) and acetone (Vetec, Rio de Janeiro, Brazil) were used to prepare the solid lipid nanoparticles (SLN) and polymeric lipid-core nanoparticles (LCN). HPLC-grade methanol was provided by Sigma-Aldrich (St. Louis, MO, USA). Water was purified in a Milli-Q Plus water purification system (Millipore, Bedford, MA, USA). All other reagents and solvents were of analytical grade.

\section{Apparatus and chromatographic conditions}

A Merck-Hitachi Lachrom HPLC (Tokyo, Japan) system, equipped with a D-7000 Interface, an L-7400 UV detector module, a L-7100 quaternary pump, and an integral degasser, was used in the method development. A manual injector (Rheodyne) system, equipped with a $20-\mu \mathrm{L}$ injector loop and a $100-\mu \mathrm{L}$ syringe (Hamilton, Microliter 710), was used. Data acquisition, analysis, and reporting were performed using ChromQuest 5.0 (Thermo Fisher Scientific, San Jose, CA, USA).

Experiments were performed in the HPLC system described above using a GL Sciences C18 Inertsil ${ }^{\circledR}$ ODS3 column (Torrance, CA, USA) of a $5-\mu \mathrm{m}$ particle size, 4.6- $\mathrm{mm}$ internal diameter, and $150-\mathrm{mm}$ length and a GL Sciences C18 Inertsil ${ }^{\circledR}$ ODS3 guard cartridge system (10 $\mathrm{mm} \times 4 \mathrm{~mm}, 5 \mu \mathrm{m})$ at $25 \pm 2{ }^{\circ} \mathrm{C}$. The mobile phase, previously filtrated using a $0.45-\mu \mathrm{m}$ PTFE membrane and degassed by sonication for $30 \mathrm{~min}$, consisted of methanol and water $(85: 15 \mathrm{v} / \mathrm{v})$ at an isocratic flow rate of $1.0 \mathrm{~mL} \cdot \mathrm{min}^{-1}$. The sample injection volume was of $20 \mu \mathrm{L}$. The halcinonide was monitored at $239 \mathrm{~nm}$. The method run time was of 10 minutes and all experiments were carried out in triplicate.

\section{Sample, standard solution, and system suitability preparation}

Halcinonide-loaded LCNs (LCN-HAL; 3.0 mg. $\mathrm{mL}^{-1}$ ) were prepared with the interfacial deposition method described by Fiel et al. (2014). The organic phase, constituted of halcinonide, sorbitan stearate, capric/ caprylic acid triglycerides, and poly( $\varepsilon$-caprolactone), was 
dissolved in acetone at $40^{\circ} \mathrm{C}$ and injected into an aqueous phase containing Tween 80 under magnetic stirring. The suspension was submitted to vacuum and to acetone evaporation. All formulations were obtained in triplicate. Unloaded-LCN was also prepared as a negative control.

Halcinonide-loaded SLNs (SLN-HAL; $3.0 \mathrm{mg} \cdot \mathrm{mL}^{-1}$ ) were obtained by hot homogenization. A lipid phase, constituted by stearic acid and halcinonide, was heated at $70{ }^{\circ} \mathrm{C}$. The aqueous phase, containing Tween 80 , was heated at the same temperature and was added to the melted lipid under stirring. The emulsion was kept in the high shear homogenizer Ultra Turrax at 18,000 rpm for $10 \mathrm{~min}$. Then, the nanoemulsion was immediately dispersed into cold distilled water $\left(2-5^{\circ} \mathrm{C}\right)$ stirred for 1 minute at 3,400 rpm to solidify the nanoparticles (Ghadiri et al., 2012). All solid lipid nanoparticles were obtained in triplicate and the unloaded-SLN was also prepared as a negative control.

\section{Method development}

The detection wavelength for the HPLC study was set at $239 \mathrm{~nm}$ after a spectrometric scanning. The chromatographic conditions were optimized for the halcinonide peak's resolution, varying the mobile phase's composition and proportion. Samples of different formulations were used to optimize the chromatographic conditions to resolve the halcinonide. These samples were filtered with a polytetrafluoroethylene (PTFE) membrane filter (Cromafil ${ }^{\circledR}$ Xtra, $0.45 \mu \mathrm{m} \times 25 \mathrm{~mm}$, MachereyNagel, Düren, Germany) before their injection into the HPLC system. An appropriate blank was injected before the analysis of every sample. The method was validated and used to determine halcinonide in the LCN and SLN nanoparticles, and to evaluate the in vitro drug permeation.

\section{Method validation}

To validate the analytical method, the guidelines established by the ICH, International Conference on the Harmonization of Technical Requirements for the Registration of Pharmaceuticals for Human Use (2005) and the Brazilian regulation (ANVISA, 2003) were employed (Gomes et al., 2015; Klein, Longhini, Mello, 2012). The method was validated for specificity, linearity, limit of detection (LOD), limit of quantitation (LOQ), accuracy, precision, and robustness.

\section{Specificity}

The specificity was determined by analyzing the chromatograms of unloaded nanoparticles in comparison with those obtained for both halcinonide-containing formulation nanoparticles (LCN-HAL and SLN-HAL), expecting the confirmation of no interference in the retention time and in the drug quantification due to formulation constituents (Gomes et al., 2015).

The nanoparticles were added in the mobile phase and kept under magnetic stirring during $24 \mathrm{~h}$. Samples was assayed in the supernatant after a suitable dilution and filtration through a $0.45-\mu \mathrm{m}$ PTFE membrane and injected into the HPLC system.

\section{Linearity}

The linearity was determined by the calculation of a regression line from the peak area's plot versus the concentration of the working standard solutions prepared at five concentration levels $(10.0 ; 15.0 ; 20.0$; 30.0 and $40.0 \mu \mathrm{g} \cdot \mathrm{mL}^{-1}$ ) and it was evaluated by the leastsquare regression analysis. A stock standard solution $\left(500 \mu \mathrm{g} . \mathrm{mL}^{-1}\right)$ was prepared daily by dissolving $5.0 \mathrm{mg}$ of halcinonide in a $10-\mathrm{mL}$ volumetric flask using the mobile phase (metanol:water 85:15, v/v). This solution was further diluted in the mobile phase to prepare the five different working standard solutions (ranging from 10 to $40 \mu \mathrm{g} . \mathrm{mL}^{-1}$ ). The solutions were injected in the HPLC column in triplicate, keeping the injection volume constant $(20 \mu \mathrm{L})$ and chromatograms were recorded. The standard deviation value for the slope, $Y$-intercept, and other statistics of the calibration curve were calculated by linear regression and analysis of variance (ANOVA).

\section{Limit of detection and limit of quantification}

The limit of detection (LOD) and limit of quantification (LOQ) were calculated based on the standard deviation (SD) and on the slope (S) of the calibration curve according to the ICH (2005) and Fuster et al. (2015) by $3.3 \mathrm{SD} / \mathrm{S}$ and $10 \mathrm{DS} / \mathrm{S}$ to LOD and to LOQ respectively.

\section{Precision}

The precision of the method was determined following the $\mathrm{ICH}$ requirements. It was evaluated at three levels: repeatability, intermediate precision, and reproducibility. The repeatability was investigated by testing six sample solutions at $25 \mu \mathrm{g} \cdot \mathrm{mL}^{-1}$, evaluated in other two different days (reproducibility) and also prepared by two operators (intermediate precision). All analyzes were performed in sextuplicate. The results were reported in terms of relative standard deviation (RSD).

\section{Accuracy}

The accuracy was determined by the analysis of three intermediate points of the calibration curve 
at different levels: low, intermediate, and high (17.5; 25.0 and $35.0 \mu \mathrm{g} . \mathrm{mL}^{-1}$, respectively). To determine the recovery known concentration of the stock solution, it was prepared to achieve the final and theoretical drug concentrations. The accuracy value was determined by calculating the percent of halcinonide recovery for these three concentration levels and then determining the RSD (Klein, Longhini, Mello, 2012; Gomes et al., 2015).

\section{Recovery}

The recovery was determined in triplicate by the preparation of a halcinonide solution of $200 \mu \mathrm{g} \cdot \mathrm{mL}^{-1}$, followed by the addition of a new halcinonide solution (500 $\left.\mu \mathrm{g} . \mathrm{mL}^{-1}\right)$, obtaining a final concentration of 700 $\mu \mathrm{g} . \mathrm{mL}^{-1}$. The samples were diluted into $25 \mu \mathrm{g} \cdot \mathrm{mL}^{-1}$ and the results were evaluated by the RSD.

\section{Robustness}

In order to determine the robustness, experimental conditions were deliberately changed to verify the method's reproducibility. It was evaluated by analyzing a halcinonide solution at a $25-\mu \mathrm{g} \cdot \mathrm{mL}^{-1}$ varying flow rate ( 0.995 and $1.005 \mathrm{~mL} . \mathrm{min}^{-1}$ ) and the composition of the mobile phase methanol:water ( $84: 16$ and $86: 14 \mathrm{v} / \mathrm{v})$. The samples were evaluated in triplicate for each variation. The chromatograms were recorded and compared with the previously reported chromatographic conditions.

\section{Evaluation of encapsulation efficiency}

To assess the halcinonide's encapsulation efficiency (EE) in lipid nanoparticles, $500 \mu 1$ of samples were filtered using an Amicon ${ }^{\circledR}$ Ultra-0.5 mL $10 \mathrm{kDa}$ filter device and centrifuged for $30 \mathrm{~min}$ at 40,000 rpm, according to Vijayakumar et al. (2016) and Zhang et al. (2016). The encapsulation efficiency was determined after the reading of the filtered samples in the HPLC, performed in triplicate and calculated using the equation (1):

$$
\mathrm{EE}(\%)=\frac{\left(\begin{array}{c}
\text { total drug } \\
\text { content }
\end{array}\right)-\left(\begin{array}{c}
\text { free drug } \\
\text { content }
\end{array}\right)}{\left(\begin{array}{c}
\text { total drug } \\
\text { content }
\end{array}\right)} \times 100
$$

\section{In vitro drug permeation}

In order to demonstrate the applicability of the validated method and the controlled drug delivery, the in vitro drug permeation of free halcinonide and of halcinonide encapsulated into LCN and SLN were evaluated. The skin permeation study was conducted in vertical diffusion cells, with a receiver compartment containing $12 \mathrm{ml}$ and an available area of $1.77 \mathrm{~cm}^{2}$. Strat ${ }^{\circledR}$ M (Merck Millipore) synthetic membranes were used in the study due to their high similarity to human skin. The samples were individually incorporated into a $0.5 \%$ Natrosol gel to increase the nanosuspension's viscosity, keeping the drug concentration at $0.1 \%$ in all samples. The membrane was placed between the donor and receiver compartment of the vertical diffusion cells. $1.0 \mathrm{~g}$ of sample-containing gel was added into the donor compartment and the system was kept under constant agitation at $37^{\circ} \mathrm{C}$. Considering the lipophilic nature of the sample, the receiver compartment was filled with isopropyl alcohol, ensuring the sink condition. Aliquots of $3.0 \mathrm{~mL}$ were withdrawn from the receiver fluid at 1,2 , $4,6,8,12$, and 24 hours and the volume was replenished. The cumulative drug that permeated was quantified using the developed and validated HPLC analytical method. The study was performed in triplicate.

\section{RESULTS AND DISCUSSION}

\section{Method development and validation}

Previous tests were carried out in order to provide a quick and effective method to analyze halcinonide using the HPLC. The investigated chromatographic conditions were mainly related to the mobile phase composition. Initial runs included 60-minute exploratory runs using a mixture of methanol and water as a mobile phase, varying the proportion of methanol from $\%$ to $95 \%$.

The mobile phase, composed by methanol:water $85: 15(\mathrm{v} / \mathrm{v})$, provided a symmetric peak for halcinonide with low retention time. The peak was detected at 4.21 min (Figure 2), which is very suitable for routine analyses. In summary, methanol:water $(85: 15 \mathrm{v} / \mathrm{v})$, a column temperature at $25 \pm 2{ }^{\circ} \mathrm{C}$, a sample injection volume of $20 \mu \mathrm{L}$, an isocratic flow rate of $1.0 \mathrm{~mL} \cdot \mathrm{min}^{-1}$, a detector set at $239 \mathrm{~nm}$, and a run time of 10 minutes were chosen as suitable chromatographic conditions for further procedures, including the method validation.

The developed method proved itself specific for halcinonide quantification from LCN and SLN (Figure 2 ), i.e. the peak related to the drug $\left(t_{R}=4.21 \mathrm{~min}\right)$ did not appear in the inert nanoparticles, indicating no interference due to nanoparticle constituents in the halcinonide quantification.

A linear relationship between the peak area and the halcinonide concentration from 10.0 to $40.0 \mu \mathrm{g} \cdot \mathrm{mL}^{-1}$ was observed (Figure 3) and the following general linear equation was obtained: $y=-8299.2874+43639.9632 x$, 


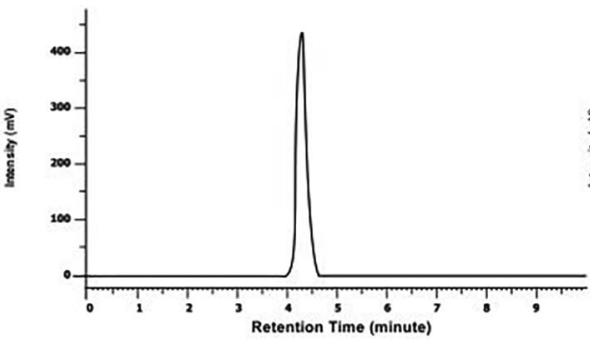

HAL

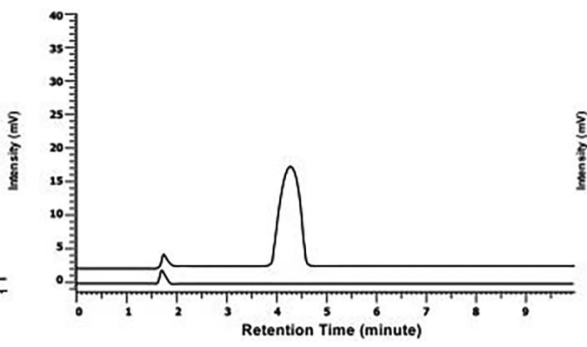

SLN

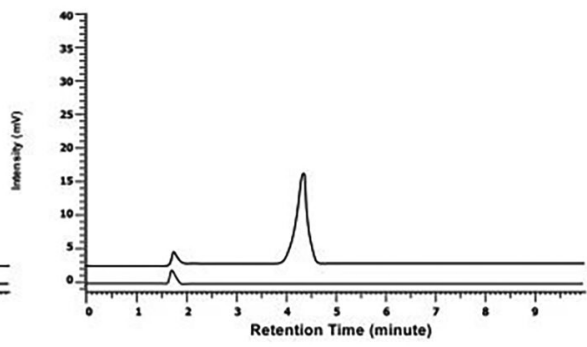

LCN

FIGURE 2 - Representative HPLC chromatograms obtained from halcinonide standard solution $\left(25.0 \mu \mathrm{g} . \mathrm{mL}^{-1}\right)$ in methanol:water and halcinonide-loaded and unloaded nanoparticles: LCN and SLN. Mobile phase: methanol:water (85:15 v/v); flow rate: $1.0 \mathrm{~mL} / \mathrm{min}$; detection wavelength: $239 \mathrm{~nm}$; column temperature: $25 \pm 2{ }^{\circ} \mathrm{C}$; and injection volume: $20 \mu \mathrm{L}$. HAL: halcinonide. Retention time: 4.21 minutes.

where $y$ is the peak area and $x$ is concentration at $\mu \mathrm{g} . \mathrm{mL}^{-1}$. A suitable correlation coefficient $(r=0.9994)$ that demonstrates that the method is linear with an $r$ value of nearly 1.0 at the purposed range was recorded. According to the Analytical Methods Committee (AMC), a regression coefficient value near to 1.0 is not necessarily the outcome of a linear relationship and, consequently, the lack-of-fit test should be applied. This test evaluates the variance of the residual values. The ANOVA test to evaluate halcinonide linearity is presented in Table I. The $F$ value for lack of fit was less than the tabulated $\mathrm{F}$ value for the $95 \%$ confidence level $(\alpha=0.05)$, and therefore, according to the ANOVA test, the linear regression showed no lack of fit (Gomes et al., 2015; Klein, Longhini, Mello, 2012).

The lowest halcinonide concentration detected (LOD) and quantified (LOQ) with acceptable precision and accuracy was 0.04 and $0.14 \mu \mathrm{g} . \mathrm{mL}^{-1}$, respectively. These results prove that the chromatographic method is suitable enough to detect and quantify halcinonide at a concentration range of 10.0 to $40.0 \mu \mathrm{g} \cdot \mathrm{mL}^{-1}$.

Precision, expressed as the RSD percentage of replicates, measures the relative errors of the method, as presented in Table II. The method developed for halcinonide quantification showed precision, because the RSD (\%) values of all parameters were less than $5.0 \%$, as established by RE 899/2003 (ANVISA).

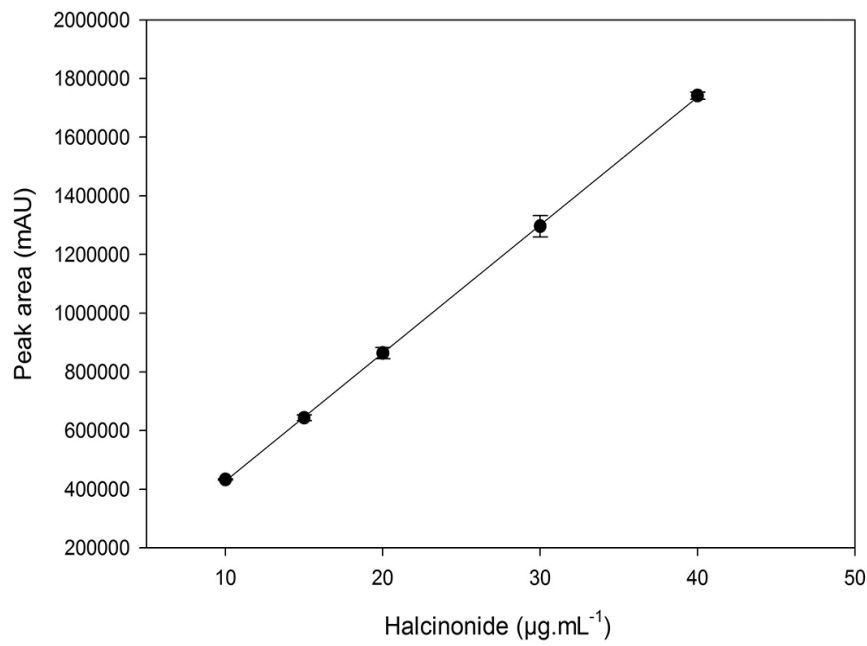

FIGURE 3 - Mean calibration curve obtained to halcinonide using working standard solutions at the concentration range from 10.0 to $40.0 \mu \mathrm{g} \cdot \mathrm{mL}^{-1}(\mathrm{n}=3)$.

The accuracy of the method refers to the proximity between the mean of the measured values and their real concentrations values (ICH, 2005). The results (Table III) agree with Fuster et al. (2015) because the mean recovery values were near to $100 \%$ and the RSD was at less than $2 \%$, thereby indicating a low variability and a strong agreement between the experimental and theoretical concentration values.

TABLE I - ANOVA linearity results

\begin{tabular}{lccccc}
\hline & $\boldsymbol{S S}$ & $\boldsymbol{D F}$ & $\boldsymbol{M S}$ & $\boldsymbol{F}$ & $\boldsymbol{F t a b}$ \\
\hline Model & $1.8581 \times 10^{8}$ & 1 & $1.8581 \times 10^{8}$ & 0.60 & 3.04 \\
Residual & $4.0503 \times 10^{9}$ & 13 & $3.1156 \times 10^{8}$ & Linear & \\
Lack of Fit & $2.2397 \times 10^{8}$ & 3 & $0.7465 \times 10^{8}$ & 0.195117 & 2.72 \\
Pure Error & $3.8263 \times 10^{9}$ & 10 & $3.8263 \times 10^{8}$ & No Lack of Fit & \\
\hline
\end{tabular}

SS: sums of squares; DF: degrees of freedom; MS: mean squares; F: F value of the test; Ftab: fixed F value. 
TABLE II - Repeatability, reproducibility and intermediate precision data of halcinonide analysis

\begin{tabular}{|c|c|c|c|}
\hline $\begin{array}{l}\text { Sample solution } \\
\left(25.0 \mu \mathrm{g} \cdot \mathrm{mL}^{-1}\right)\end{array}$ & $\begin{array}{c}\text { Experimental concentration } \\
\left(\mu \mathrm{g} \cdot \mathrm{mL}^{-1} \pm \mathrm{SD}^{*}\right) \\
\end{array}$ & $\begin{array}{c}\text { Recovered } \\
(\%)\end{array}$ & $\begin{array}{c}\text { RSD }^{* *} \\
(\%)\end{array}$ \\
\hline Repetability $(n=6)$ & $25.90 \pm 0.75$ & $103.60 \pm 2.99$ & 2.88 \\
\hline \multicolumn{4}{|l|}{ Reproducibility $(n=6)$} \\
\hline Day 1 (morning) & $25.61 \pm 0.28$ & $102.45 \pm 1.14$ & 1.09 \\
\hline Day 2 (morning) & $25.10 \pm 0.52$ & $102.09 \pm 4.46$ & 4.37 \\
\hline Day 1 (afternoon) & $25.23 \pm 0.34$ & $100.93 \pm 1.36$ & 1.35 \\
\hline \multicolumn{4}{|c|}{ Intermediate precision $(n=6)$} \\
\hline Analyst 1 & $25.87 \pm 0.83$ & $103.48 \pm 3.33$ & 3.21 \\
\hline Analyst 2 & $25.72 \pm 0.33$ & $102.90 \pm 1.33$ & 1.29 \\
\hline
\end{tabular}

*SD: standard deviation; **RSD: relative standard deviation.

TABLE III - Accuracy assays for halcinonide analysis

\begin{tabular}{|c|c|c|c|c|}
\hline Level of concentration & $\begin{array}{c}\text { Theoretical } \\
\text { concentration } \\
\left(\mu \mathrm{g} \cdot \mathrm{mL}^{-1}\right)\end{array}$ & $\begin{array}{c}\text { Experimental } \\
\text { concentration } \\
\left(\mu \mathrm{g} . \mathrm{mL}^{-1} \pm \mathrm{SD}^{*}\right) \\
\end{array}$ & $\begin{array}{c}\text { Recovered } \\
(\%)\end{array}$ & $\begin{array}{c}\text { RSD }^{* *} \\
(\%)\end{array}$ \\
\hline$\overline{L o w}$ & 17.5 & $16.68 \pm 0.25$ & $95.31 \pm 1.44$ & 1.51 \\
\hline Medium & 25.0 & $24.52 \pm 0.18$ & $98.06 \pm 0.72$ & 0.73 \\
\hline High & 35.0 & $34.35 \pm 0.30$ & $98.14 \pm 0.89$ & 0.90 \\
\hline
\end{tabular}

*SD: standard deviation; **RSD: relative standard deviation.

TABLE IV - Recovery assays for halcinonide analysis

\begin{tabular}{cccc}
\hline $\begin{array}{c}\text { Theoretical concentration } \\
\left(\boldsymbol{\mu g} . \mathbf{m L}^{-1}\right)\end{array}$ & $\begin{array}{c}\text { Experimental concentration } \\
\left(\boldsymbol{\mu g .} \cdot \mathbf{m L}^{-1} \pm \mathbf{S D}^{*}\right)\end{array}$ & $\begin{array}{c}\text { Recovered } \\
(\mathbf{\%})\end{array}$ & $\begin{array}{c}\text { RSD }^{* *} \\
\mathbf{( \% )}\end{array}$ \\
\hline 200 & $198.48 \pm 6.18$ & $99.24 \pm 3.09$ & 3.11 \\
700 & $704.60 \pm 22.69$ & $100.65 \pm 3.24$ & 3.22 \\
\hline
\end{tabular}

*SD: standard deviation; **RSD: relative standard deviation.

Results of recovery are shown in Table IV. The development method presented a recovery less than 5.0 $\%$ of RSD, with a recovery percentage near to $100 \%$, in accordance to what was established by RE $899 / 2003$ (ANVISA).

The robustness of an analytical procedure measures its capacity to remain unaffected by small, but deliberate, variations in the method parameters, and provides an indication of its reliability during normal usage ( $\mathrm{ICH}$, 2005). The method was considered robust because the RSD values were less than $1.54 \%$ for the drug content, as summarized in Table $\mathrm{V}$, indicating that the deliberate variation of the method conditions had no significant effect on assay data or on chromatographic performance (Fontana, Bastos, Beck, 2010), not affecting the analysis of halcinonide in lipid nanoparticles.

\section{Encapsulation efficiency}

The drug content and encapsulation efficiency (EE) of halcinonide in lipid nanoparticles was carried out by the previously validated HPLC method and the results obtained are presented in Table VI. High percentages of entrapped drug were obtained for lipid nanoparticles in both types. All formulations presented suitable EE values greater than $99 \%$. These values are mainly based on the poor aqueous solubility of halcinonide and on its high partition coefficient $(\log \mathrm{P}=3.31)$, which leads to high drug load quantities in lipid nanoparticles. The current results are similar to the ones previously reported by Silva et al. (2015) on the EE of betamethasone (topical glucocorticoid) in nanoparticles using a similar method for quantification. 
TABLE V - Robustness for halcinonide analysis

\begin{tabular}{lccc}
\hline Conditions & $\begin{array}{c}\text { Experimental concentration } \\
\left(\boldsymbol{\mu g} \cdot \mathbf{m L}^{-1} \pm \mathbf{S D}^{*}\right)\end{array}$ & $\begin{array}{c}\text { Recovered } \\
(\mathbf{\%})\end{array}$ & $\begin{array}{c}\text { RSD** }^{* *} \\
(\mathbf{\%})\end{array}$ \\
\hline Flow rate & & & 1.00 \\
$\quad 0.995 \mathrm{~mL} \cdot \mathrm{min}^{-1}$ & $25.89 \pm 0.26$ & $103.56 \pm 1.05$ & 1.54 \\
$1.005 \mathrm{~mL} \cdot \mathrm{min}^{-1}$ & $26.00 \pm 0.41$ & $104.03 \pm 1.64$ & \\
Mobile phase & & & 0.90 \\
$84: 16$ & $26.25 \pm 0.24$ & $105.00 \pm 0.95$ & 0.70 \\
$86: 14$ & $26.48 \pm 0.19$ & $105.93 \pm 0.75$ & \\
\hline
\end{tabular}

*SD: standard deviation; **RSD: relative standard deviation.

TABLE VI - Halcinonide-loaded and encapsulation efficiency (EE) for polymeric lipid-core nanoparticles (LCN) and solid lipid nanoparticles (SLN)

\begin{tabular}{lccc}
\hline Lipid nanoparticle sample & $\begin{array}{c}\text { Theoretical concentration } \\
\left(\mu \mathrm{g} \cdot \mathrm{mL}^{-1} \pm \mathrm{SD}^{*}\right)\end{array}$ & $\begin{array}{c}\text { Experimental concentration } \\
\left(\mu \mathrm{g} \cdot \mathrm{mL}^{-1} \pm \mathrm{SD}\right)\end{array}$ & $\begin{array}{c}\text { EE } \\
(\% \pm \mathrm{SD})\end{array}$ \\
\hline LCN-HAL & 3000 & $2997.09 \pm 1.14$ & $99.90 \pm 0.04$ \\
SLN-HAL & 3000 & $2999.01 \pm 0.10$ & $99.96 \pm 0.01$ \\
\hline
\end{tabular}

*SD: standard deviation. HAL: halcinonide.

\section{In vitro permeation study}

The permeation profile of pure halcinonide and halcinonide-loaded LCN and SLN are shown in Figure 4. An increase of pure halcinonide percentage in the receptor chambers with time was observed until $12 \mathrm{~h}$. The permeation rates of pure halcinonide from Natrosol gel were about $18 \%$ and $50 \%$ during 6 and 24 hours,

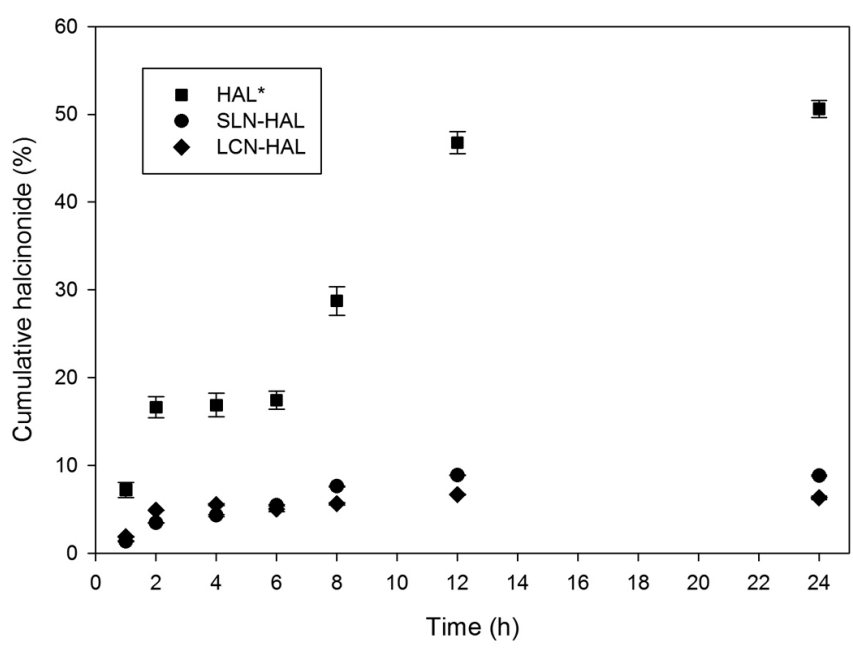

FIGURE 4 - In vitro cumulative permeation-time profile of halcinonide and halcinonide-loaded lipid nanoparticles. HAL: halcinonide. *represent statistical different result; Student's $t$-test $(\alpha=0.05)$. respectively. Since the synthetic membrane used has similarities to the human skin, halcinonide can permeate through the stratum corneum barrier due to its lipophilic character, reaching the dermis and being absorbed.

The halcinonide-loaded lipid nanoparticle profile presented no more than $9 \%$ of permeated halcinonide and there was no skin permeation difference between the LCN and the SLN during $24 \mathrm{~h}$ ( $\mathrm{p}>0.05, t$-test). This result indicates that despite the nature of the lipid nanoparticles, which could promote the permeation of the drug, the reservoir effect promoted by the LCN and the SLN was essential to control the halcinonide release.

With the purpose of obtaining drug quantification, both for EE and in vitro drug permeation, the validated method was successfully applied in the determination of halcinonide in lipid nanoparticles-LCN and SLN-and it can be considered an important tool for the quality control of these promising formulations.

\section{CONCLUSION}

A simple and effective HPLC method was developed and validated for the quantitative determination of halcinonide in lipid nanoparticles-LCN and SLN. This method was considered specific, linear, accurate, precise, and robust for a quick determination of halcinonide in lipid nanoparticles according to the ICH guideline and the Brazilian regulation (RE 899/2003). Furthermore, the 
drug content and the encapsulation efficiency were quickly and suitably determined, as well as the halcinonide in vitro permeation profile, displaying a controlled drug release and indicating a possible reduction of halcinonide toxicity due to its nanoencapsulation.

\section{ACKNOWLEDGMENTS}

This work was supported by CNPq and UEPG (State University of Ponta Grossa).

\section{REFERENCES}

AGÊNCIA NACIONAL DE VIGILÂNCIA SANITÁRIA. ANVISA. Resoluçao no 899, de 29 de maio de 2003. Diário Oficial [da] República Federativa do Brasil, Brasília, DF, 02 de julho de 2003.

BRUM, T.L.; FIEL, L.A.L.; CONTRI, R.V.; GUTERRES, S.S.; POHLMANN, A.R. Polymeric nanocapsules and lipid-core nanocapsules have diverse skin penetration. J. Nanosci. Nanotechnol., v.15, n.1, p.773-780, 2015.

CHEN, H.; CHANG, X.; DU, D.; LIU, W.; LIU, J.; WENG, T.; YANG, Y.; XU, H.; YANG, X. Podophyllotoxin-loaded solid lipid nanoparticles for epidermal targeting. J. Control. Release, v.110, n.2, p.296-306, 2006.

CORADINI, K.; LIMA, F.O.; OLIVEIRA, C.M.; CHAVES, P. S.; ATHAYDE, M.L.; CARVALHO, L.M.; BECK, R.C.R. Co-encapsulation of resveratrol and curcumin in lipid-core nanocapsules improves their in vitro antioxidant effects. Eur. J. Pharm. Biopharm., v.88, n.1, p.178-185, 2014.

FIEL, L.A.; PAESE, K.; RIZZI, M.; GUTERRES, S.S.; POHLMANN, A.R. A strategy to estimate the intrinsic flux of a poorly water soluble substance for comparison with its release from lipid-corenanocapsules. Colloid Surf. A, v.441, p.716-724, 2014.

FONTANA, M.C.; BASTOS, M.O.; BECK, R.C.R. Development and validation of a fast RP-HPLC method for the determination of clobetasol propionate in topical nanocapsule suspensions. J. Chromatogr. Sci., v.48, n.8, p.637-40, 2010.
FUSTER, J.; NEGRO, S.; SALAMA, A.; FERNÁNDEZCARBALLIDO, A.; MARCIANES, P.; BOEVA, L.; BARCIA, E. HPLC-UV method development and validation for the quantification of ropinirole in new PLGA multiparticulate systems: Microspheres and nanoparticles. Int. J. Pharm., v.491, n.1, p.310-317, 2015.

GHADIRI, M.; FATEMI, S.; VATANARA, A.; DOROUD, D.; NAJAFABADI, A.R.; DARABI, M.; RAHIMI, A.A. Loading hydrophilic drug in solid lipid media as nanoparticles: statistical modeling of entrapment efficiency and particle size. Int. J. Pharm., v.424, n.1, p.128-137, 2012.

GOMES, M.L.S.; KLEIN, T.; SIMIONATTO, M.; NADAL, J.M.; ZANIN, S.M.W.; BORSATO, D.M.; FARAGO, P.V. A simple RP-HPLC/UV method for determination of cilostazol in polymeric nanoparticles suspensions: development and validation. Lat. Am. J. Pharm., v.34, n.4, p.803-809, 2015.

GUICHARD, A.; HUMBERT, P.; TISSOT, M.; MURET, P.; COUDEROT-MASUYER, C.; VIENNET, C. Effects of topical corticosteroids on cell proliferation, cell cycle progression and apoptosis: In vitro comparison on $\mathrm{HaCaT}$. Int. J. Pharm., v.479, n.2, p.422-429, 2015.

HENGEE, U.R.; RUZICKA, T.; SCHWARTZ, R.A.; CORK, M.J. Adverse effects of topical glucocorticosteroids. J. Am. Acad. Dermatol., v.54, n.1, p.1-15, 2006.

INTERNATIONAL CONFERENCE ON HARMONISATION. ICH. Technical requirements for registration of pharmaceuticals for human use. Quality Guideline: view all quality guidelines. analytical validation Q2. Q2 (R1) validation of analytical procedures: text and methodology. Geneva: ICH, 2005.

JÄGER, A.; STEFANI, V.; GUTERRES, S.S.; POHLMANN, A.R. Physicochemical characterization of nanocapsule polymeric wall using fluorescent benzazole probes. Int. J. Pharm., v.338, n.1-2, p.297-305, 2007.

KELIDARI, H.R.; SAEEDI, M.; AKBARI, J.; MORTEZASEMNANI, K.; GILL, P.; VALIZADEH, H.; NOCHODCHIA, A. Formulation optimization and in vitro skin penetration of spironolactone loaded solid lipid nanoparticles. Colloid Surf. B, v.128, p.473-479, 2015. 
KIRSCHBAUM, J.; POET, R.; BUSH, K.; PETRIE, G. Highperformance liquid chromoatography of the topical antiinflammatory steroid halcinonide. J. Chromatogr., v.190, n. 2, p.481-485, 1980.

KLEIN, T.; LONGHINI, R.; MELLO, J.C.P. Development of an analytical method using reversed-phase HPLC-PDA for a semipurified extract of Paullinia cupana var. sorbilis (guaraná). Talanta, v.88, p.502-506, 2012.

MADAM, J.R.; KHUDE, P.A.; DUA, K. Development and evaluation of solid lipid nanoparticles of mometasone furoate for topical delivery. Int. J. Pharm. Invest., v.4, n.2, p.60-64, 2014.

MAIA, C.S.; MEHNERT, W.; SCHAFER-KORTING, M. Solid lipid nanoparticles as drug carriers for topical glucocorticoids. Int. J. Pharm., v.196, n.2, p.165-167, 2000.

SCHACKE, H.; DOCKE, W.-D.; ASADULLAH, K. Mechanisms involved in the side effects of glucocorticoids. Pharmacol. Ther., v.96, n.1, p.23-43, 2002.

SCHAFFAZICK, S.R.; GUTERRES, S.S. Caracterização e estabilidade físico-química de sistemas poliméricos nanoparticulados para administração de fármacos. Quim. Nova, v.26, n.5, p.726-737, 2003.

SENYIGIT, T.; OZER, O. Corticosteroids for skin delivery: challenges and new formulation opportunities. In: QIAN, X. Glucocorticoids: new recognition of our familiar friend. Rijeka, Croatia: InTech, 2012. Chap. 24.
SHAH, B.; KHUNT, D.; BHATT, H.; MISRA, M.; PADH, H. Application of quality by design approach for intranasal delivery of rivastigmine loaded solid lipid nanoparticles: effect on formulation and characterization parameters. Eur. J. Pharm. Sci., v.78, p.54-66, 2015.

SILVA, C.O.; RIJO, P.; MOLPECERES, J.; FIGUEIREDO, I.V.; ASCENSÃO, L.; FERNANDES, A.S.; ROBERTO, A.; REIS, C.P. Polymeric nanoparticles modified with fatty acids encapsulating betamethasone for anti-inflammatory treatment. Int. J. Pharm., v.493, n.1, p.271-284, 2015.

TAHERI, A.; FELDMAN, S.R. Halcinonide: a review of its clinical merits. Curr. Clin. Solutions, p.1-5, Dec. 2012.

VENTURINI, C.G.; JÄGER, E.; OLIVEIRA, C.P.; BERNARDI, A.; BATTASTINI, A. M.O.; GUTERRES, S.S.; POHLMANN, A.R. Formulation of lipid core nanocapsules. Colloid Surf. A, v.375, n.1-3, p.200-208, 2011.

VIJAYAKUMAR, A.; BASKARAN, R.; JANG, Y.S; OH, S.H.; YOO, B.K. Quercetin-loaded solid lipid nanoparticle dispersion with improved physicochemical properties and cellular uptake. AAPS PharmSciTech., 2016. [Ahead of print]. DOI:10.1208/s12249-016-0573-4.

ZHANG, Y.; LI, Z.; ZHANG, K.; YANG, G.; WANG, Z.; ZHAO, J.; HU, R.; FENG, N. Ethyl oleate-containing nanostructured lipid carriers improve oral bioavailability of trans-ferulic acid as compared with conventional solid lipid nanoparticles. Int. J. Pharm., v.511, n.1, p.57-64, 2016.

Received for publication on $22^{\text {nd }}$ December 2015 Accepted for publication on $19^{\text {th }}$ December 2016 